\title{
USE OF INTEGRATED APPROACH TO DISPARITIES EVALUATION IN COUNTRIES AND REGIONS OF VISEGRAD FOUR IN COMPARISON WITH AUSTRIA AND GERMANY
}

\author{
[Využití integrovaného př́stupu $\mathrm{k}$ hodnocení disparit $\mathrm{v}$ zemích a regionech \\ Visegrádské čtyřky v porovnání s Rakouskem a Německem]
}

\author{
Lukáš Melecký $^{1}$, Michaela Staníčková ${ }^{2}$ \\ ${ }^{1}$ VŠB-Technical University of Ostrava, Faculty of Economics, Sokolská trída 33, 70121 Ostrava \\ Email:lukas.melecky@vsb.cz \\ ${ }^{2}$ VŠB-Technical University of Ostrava, Faculty of Economics, Sokolská třida 33, 70121 Ostrava \\ Email: michaela.stanickova@vsb.cz.
}

\begin{abstract}
The paper evaluates the level of economic, social and territorial disparities in 6 selected EU Member States and 83 NUTS 2 regions in case of Visegrad Four, Austria and Germany during reference period 2000-2010. The evaluation analysis is based on selected mathematical and statistical methods that lead to construction of simple (non-weighted) synthetic indices of economic, social and territorial disparities and weighted synthetic aggregate index of disparities. The theoretical part of the paper defines the concept of disparities and cohesion in the EU and methodological background of convenient statistical methods for regional disparities evaluation. The empirical part of the paper deals with the measurement, evaluation and comparison of disparities rates in all the selected EU countries and NUTS 2 regions through computed values of synthetic sub-indices of economic, social and territorial disparities and weighted (aggregate) synthetic index of disparities. All the synthetic indices are calculated on the basis of Z-score standardized variables using Euclidean distance method.
\end{abstract}

Keywords: Austria, cohesion, disparities, Germany, indices of disparities, integrated approach, NUTS 2, Visegrad Four.

JEL classification: $\mathrm{C} 02, \mathrm{O} 18, \mathrm{R} 11, \mathrm{Y} 10$

Doručeno redakci: 7.1.2013; Recenzováno: 10.5.2013; 29.5.2013; Schváleno k publikování: 16.6.2014

\section{Introduction}

The European Union (EU) is a heterogeneous unit with significant disparities between its Member States and especially their regions. The support of cohesion and balanced development together with increasing level of EU competitiveness belong to the temporary EU's key development objectives. The process of European integration is thus guided by striving for two different objectives: to foster economic competitiveness and to reduce territorial differences (Molle, 2007). Although the EU is one of the most developed world integration with high living standards, there exist significant economic, social and territorial disparities having a negative impact on the balanced development across EU Member States and their regions, and thus weaken EU's performance in a global context. Disparities measurement and evaluation at any level of territorial development is associated with the lack of integrated approaches and methodologies in most cases. Within this paper, the application of integrated approach by using construction of three synthetic non-weighted indices and one weighted synthetic index of disparities are introduced in the topic of disparities in the Visegrad Four (V4) countries, i.e. the Czech Republic, Hungary, Poland and Slovakia in comparison with selected advanced EU countries, i.e. Germany and Austria in national and regional level. The main goal of the paper is a verification of synthetic indices approach through evaluation of economic, social and territorial disparities that reflect the level of cohesion in the evaluated countries and regions in reference period 2000-2010. For this 
purpose, the paper will determinate and compute three synthetic indices of economic, social and territorial disparities and propose a construction of weighted (aggregate) synthetic index of disparities. The hypothesis of the paper is based on the generally accepted concept of Willem Molle (2007), that countries/regions with the lower level of disparities achieve the higher level of cohesion in the territory that provides better conditions and assumptions for regional development potential, and vice versa. The paper, in content of previous hypothesis, intends to establish the general presumption that in country (and also regions) of the selected developed EU Member States, i.e. Austria, Germany is lower level of national (and also regional) disparities in comparison with the level of national (regional) disparities in territory of less developed V4 countries in all three explored dimensions of disparities.

\section{Theoretical Background of Disparities in the Context of Cohesion}

Disparities in the frame of regional development are a major obstacle to the balanced and harmonious development of the whole territory (country, region). Analysis of disparities brings the important information about the key problematic issues in region (and thus in country) on the one hand and its development potential on the other hand. There are different approaches to definition of regional disparities (also in the European Union) and therefore this term can be understood as a multidimensional problem (Kutscherauer, 2010). Based on the literature review focused on several foreign and domestic theoretical and empirical studies dealing with the measurement and evaluation of disparities in the context of the EU (see e.g. Wishlade, Yuill (1997), Gulati, (1999), Amendola, Caroleo, Coppola, (2004), Leonardi, (2005), Molle (2007), Farrugia and Gallina (2008), Tuleja, (2008), Kutscherauer, (2010), Viturka, (2010), Vojvodíková, (2010), Tvrdoň and Skokan (2011), Petr, Křupka, Provazníková, (2011) or Poledníková and Lelková (2012)) we recognize three general types of regional disparities: economic, social and territorial. Economic disparities represent different level of economic convergence of countries and regions (Molle, 2007) that can be measured by economic indicators. Social disparities are related to how people perceive spatially differentiated quality of the life, standard of living or social inequality (Molle, 2007) and they are mostly measured by the indicators of the labour market. Territorial disparities reflect the strong inequalities in the EU competitiveness factors. Territory inequality is expressed by the significant differences in the economic performance, geographical potential and transport and technical infrastructure, capacity for innovations or quality of environment (Molle, 2007). In the European concept, the level of disparities can be regarded as a measure of cohesion. By Molle (2007, p. 5), the cohesion can be expressed by such level of differences between countries, regions or groups that are politically and socially tolerable. Based on typology of disparities, three dimensions of cohesion are recognized, i.e. economic, social and territorial. Economic cohesion evaluates economic convergence and can be expressed by disparities reducing development levels of countries and regions by economic indicators. Social cohesion tends to achieve objectives in employment and unemployment, education level, social exclusion of different groups and in demographic trends. Territorial cohesion is a supplementary term to economic and social cohesion. This concept develops economic and social cohesion by transferring the basic objective of EU, i.e. balanced and sustainable development into territorial context (Kutscherauer, 2010).

\section{Selected Approaches of Disparities Measurement and Evaluation}

Approaches of disparities measurement differ in structure of using the disparities indicators and ways of their processing. In the current regional practice, the methods based on crosscountry (interregional) comparison or mathematical and statistical methods are often used. Among disparities assessment methods we can namely included interregional comparison method (see e.g. Amendola, Caroleo, Coppola, (2004), Kutscherauer, (2010) or Poledníková 
and Lelková (2012)); methods utilizing Geographical information system (see e.g. Bell, Schuurman, Hayes, (2007), ESRI, (2008); variability characteristics, i.e. standard deviations and variation coefficients (see e.g. Huang and Leung (2009), Tvrdoň, Skokan, (2011); multivariate statistical methods (e.g. method of main components and factor, cluster or discrimination analyses (see e.g. Hančlová et al, (2010); method of real convergence (see e.g. Vojinovic, Oplotnik, (2008), Dvoroková, Kovářová, Sulgánová (2011)); modified territorial Gini coefficient or method of artificial neuron nets (e.g. (Kutscherauer, (2010), Tvrdoň, Skokan, (2011)). The adequate indicators of national or regional disparities can be identified e.g. within the Reports on Economic, Social and Territorial Cohesion published by the European Commission (2007; 2010). Other possible indicators appropriate for the evaluation of disparities are the EU Structural indicators or headline indicators for evaluation of achieving the targets of Strategy Europe 2020 (e.g. Hančlová et al (2010), Staníčková, Skokan (2012)). Within the aim and scope of the paper, the selected mathematical and statistical methods as methods of standardized variable, i.e. transformation methods based on the normal distribution function (z-score) and method of distance from the imaginary point for partial calculation of synthetic indices of disparities have been used. These methods are often used to identification of the level of disparities and thus to evaluation of cohesion (see e.g. Tuleja, (2008, 2010), Křupka, Provazníková, Švejcar, (2011), Petr, Křupka, Provazníková, (2011) or (Melecký, 2012))

\subsection{Z-Score Transformation Method}

Transformation function in the multidimensional context should satisfy at least two conditions. First, since the attributes (indicators) are measured in different units, they must be transformed into a common scale for aggregation. Second, the functions should avoid assigning high relative importance to extreme values if the original distribution has extreme values. Transformation of original variables therefore can be used to construct a multidimensional indicator, such as synthetic indices of disparities. The most commonly used transformation methods include standardization of variable based on range, on the normal distribution function (z-score) or on the distance from the optimal value achieved by the attribute. As the application of classic data normalization method, we use Z-score transformation that provides a way of standardizing data across a wide range of disparities indicators. Data normalized by Z-score transformation are directly used in the calculation of synthetic indices of economic, social and territorial disparities. Z-score transformation of selected disparities indicators values for countries as well as for NUTS 2 regions used in the paper is calculated by equation (1):

$$
u_{i, c(r), t}=\frac{x_{i, c(r), t}-\bar{x}_{t}}{\hat{s}_{i, t}}
$$

where:

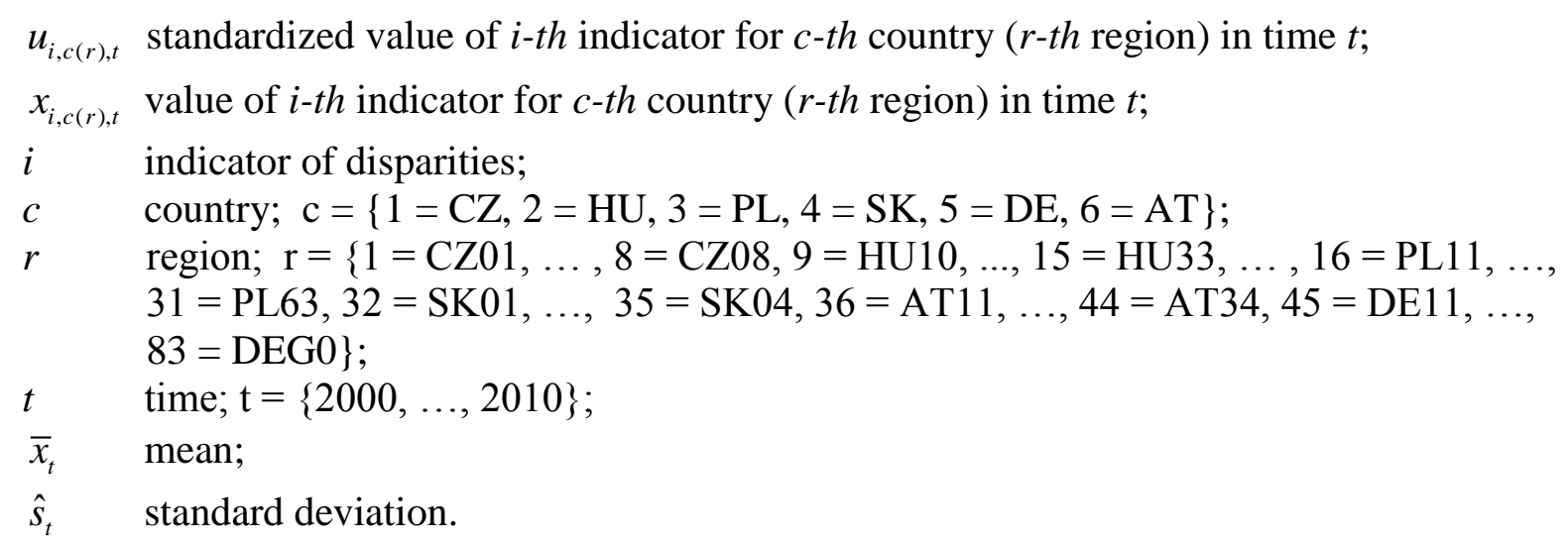


The Z-score standardized value has mean $\left(\bar{x}_{t}\right)$ equals 0 and standard deviation $\left(\hat{s}_{t}\right)$ equals 1 . However, Z-scores take decimal values and can be also negative.

\subsection{Euclidean Distance Method}

Z-score transformation is an example of linear transformation and thus it changed scaling uniformly, but it doesn't define the distance between standardized values. There are several convenient methods applicable for calculation of distance from the imaginary point that is usually presented as an optimal value. The most common way of computing distance between objects in a multidimensional space is to compute Euclidean distances, an extension of Pythagoras' theorem. The Euclidean distance is the square root of the sum of the squared differences in the variables' values; see e.g. (Farrugia, Gallina, 2008). As optimal value in computing of Euclidean distance in the paper analysis, the median is used. Euclidean distance for $i$-th indicator and $c$-th country in time $t$ is calculated by equation (2):

$$
E_{i, c(r), t}=\left(u_{i, c(r), t}-\hat{u}_{50 i}\right)^{2}
$$

where:

E Euclidean distance;

$u_{i, c(r), t}$ standardized value of $i$ - $t$ indicator for $c$-th country ( $r$-th region) in time $t$;

$\hat{u}_{50 i} \quad$ median for $i$-th indicator;

$i \quad$ indicator of disparities;

c country; $\mathrm{c}=\{1=\mathrm{CZ}, 2=\mathrm{HU}, 3=\mathrm{PL}, 4=\mathrm{SK}, 5=\mathrm{DE}, 6=\mathrm{AT}\}$;

$r \quad$ region; $\mathrm{r}=\{1=\mathrm{CZ01}, \ldots, 8=\mathrm{CZ} 08,9=\mathrm{HU} 10, \ldots, 15=\mathrm{HU} 33, \ldots, 16=\mathrm{PL} 11, \ldots$, $31=$ PL63, $32=\mathrm{SK} 01, \ldots, 35=\mathrm{SK} 04,36=\mathrm{AT} 11, \ldots, 44=\mathrm{AT} 34,45=\mathrm{DE} 11, \ldots$, $83=$ DEG0 $\}$

$t \quad$ time; $\mathrm{t}=\{2000, \ldots, 2010\}$.

\section{Construction of Synthetic Indices of Disparities}

The construction of synthetic indices (non-weighted or weighted) of disparities for evaluation of national (country) disparities and derivation the level of cohesion includes dataset of 24 selected indicators of disparities. Analysis and evaluation of regional (NUTS 2 level) disparities and derivation of the level of cohesion at regional level is based on the same dataset (but reduced due to availability) of 16 selected indicators of disparities. Each dimension of disparities is presented by selected indicators listed in Table 2. The construction of indices has been inspired by approaches of Farrugia and Gallina (2008) that proposed construction of index of territorial disparities and also by Bárcena et al. (Bárcena, Prado, Beccaria, Malchik, 2004) that evaluated social cohesion in Latin America by construction of index of social cohesion. Synthetic indices are computed as partial simple sub-indices for each individual dimension of regional disparities (Melecký, 2012). Synthetic indices (ID) of each country $c$ (or region $r$ ), for each dimension of disparities $d$, in time $t$ are calculated by equation (3):

$$
I D_{c(r), d, t}=\frac{\sum_{i=1}^{I} E_{i, c(r), t}}{I}
$$

where:

ID index (sub-index) of disparities;

E Euclidean distance;

$c \quad$ country; $\mathrm{c}=\{1=\mathrm{CZ}, 2=\mathrm{HU}, 3=\mathrm{PL}, 4=\mathrm{SK}, 5=\mathrm{DE}, 6=\mathrm{AT}\}$; 


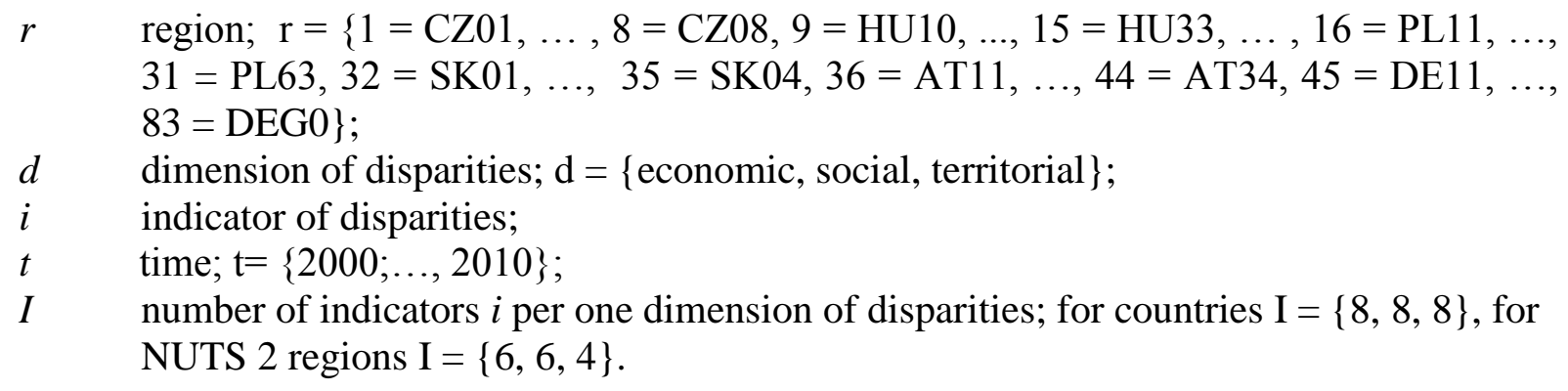

The construction of weighted synthetic index of disparities has been met with problems related to the weighting. We can aggregate data by using equal or differential weight given to all free dimensions of disparities (Melecký, 2012). On the background of descriptive statistics and variability of selected dataset of indicators, we have used differential weights for each dimension; however, some research may prove equal weighting (e.g. Farrugia, Gallina, 2008). Weights used in construction of weighted synthetic index presented in equation (5) are calculated by equation (4). Weights are designed and based on the rates of variability (variability characteristics), which express the distribution of values of a given variable around the mean value of the whole set of data. Therefore, weights reflect how values in the set of data are scattered around the centre, or whether there are extreme values in the set of data. Like a variability characteristic, the Range has been used. Range presents a descriptive statistic of absolute variability of a set of data. It is the difference between the largest and smallest values. It is the size of the smallest interval which contains all the data and provides an indication of statistical dispersion. It is measured in the same units as the data. Since it only depends on two of the observations, it is most useful in representing the dispersion of small data sets (Woodbury, 2001, p. 74). Range $R$ presented in equation (4) expresses difference between the largest (maximum) and smallest (minimum) scores of each calculated synthetic sub-index of disparities.

$$
w_{d}=\frac{\sum_{t=1}^{T} R_{c(r)} I D_{c(r), d, t}}{T}
$$

where:

$$
\begin{array}{ll}
\underset{c(r)}{R} I D_{c(r), d, t} & \text { Range of each calculated synthetic sub-index of disparities of country } c \text { (region } \\
& r) \text { in time } t ; \\
& \quad \underset{c(r)}{R} I D_{c(r), d, t}=I D_{c(r), d, t_{\max }}-I D_{c(r), d, t_{\min }}, \text { where } I D_{c(r), d, t_{\max }} \text { is maximum } \\
& \text { value of index of disparities of country } c(\text { region } r) \text { for dimension } d \text { in time } t ; \\
& I D_{c(r), d, t_{\min }} \text { is minimum value of index of disparities of country } c \text { (region } r \text { ) } \\
& \text { for dimension } d \text { in time } t ; \\
& \text { index }(\text { sub-index) of disparities; } \\
w_{d} & \text { weight per dimension of disparities; } \\
d & \text { dimension of disparities; } \mathrm{d}=\{\text { economic, social, territorial }\} ; \\
t & \text { time; } \mathrm{t}=\{2000 ; \ldots, 2010\} ; \\
T & \mathrm{~T}=11 .
\end{array}
$$

Weighted synthetic index (WID) is calculated from the partial indices of disparities for country $c$ (region $r$ ), for dimension $d$ in time $t$ by equation (5) on condition (6): 


$$
\begin{aligned}
& W I D_{c(r), d, t}=\sum_{d=1}^{3} I D_{c(r), t, d} \cdot \frac{w_{d}}{\sum_{d=1}^{3} w_{d}} \\
& \text { on condition: } \sum_{d=1}^{3} \frac{w_{d}}{\sum w_{d}}=1
\end{aligned}
$$

where:

WID

$I D$

$w_{d}$

$\frac{w_{d}}{\sum_{d=1}^{3} w_{d}}$

$d$

$c$

$r$

weighted synthetic index of disparities of region $r$ for dimension $d$ in time $t$; index (sub-index) of disparities of region $r$ for dimension $d$ in time $t$; weight per dimension of disparities; relative weight per dimension of disparities $d$ in relation to other dimensions of disparities in period $t$;

dimension of disparities; $\mathrm{d}=\{$ economic, social, territorial $\}$; country; $\mathrm{c}=\{1=\mathrm{CZ}, 2=\mathrm{HU}, 3=\mathrm{PL}, 4=\mathrm{SK}, 5=\mathrm{DE}, 6=\mathrm{AT}\}$; region; $\mathrm{r}=\{1=\mathrm{CZ} 01, \ldots, 8=\mathrm{CZ} 08,9=\mathrm{HU} 10, \ldots, 15=\mathrm{HU} 33, \ldots, 16=$ PL11, .., $31=$ PL63, $32=\mathrm{SK} 01, \ldots, 35=\mathrm{SK} 04,36=\mathrm{AT} 11, \ldots, 44=\mathrm{AT} 34$, $45=\mathrm{DE} 11, \ldots, 83=\mathrm{DEG} 0\}$;

time; $\mathrm{t}=\{2000 ; \ldots, 2010\}$.

\section{Empirical Analysis of Disparities and Evaluation of Cohesion in Visegrad Countries, Germany and Austria by Synthetic Indices of Disparities \\ 4.1 Background of Empirical Analysis}

The analysis of economic, social and territorial disparities is based on 24 selected indicators of disparities in countries and 16 selected indicators of disparities in NUTS 2 regions. Each dimension of disparities is presented by selected indicators listed in Table 2 . The reference period (2000-2010) is determined by selection of all the indicators and their data availability mainly in territorial unit NUTS 2 for 83 regions of 6 countries, i. e. V4, Austria and Germany. We have used the European Statistical Office database (Eurostat, 2012) as basic source of disparities indicators. Procedure of empirical analysis of cohesion evaluation in selected EU Member States and their NUTS 2 regions is based on the procedure scheme listed in Table 1.

Table 1: Basic scheme of empirical analysis approach

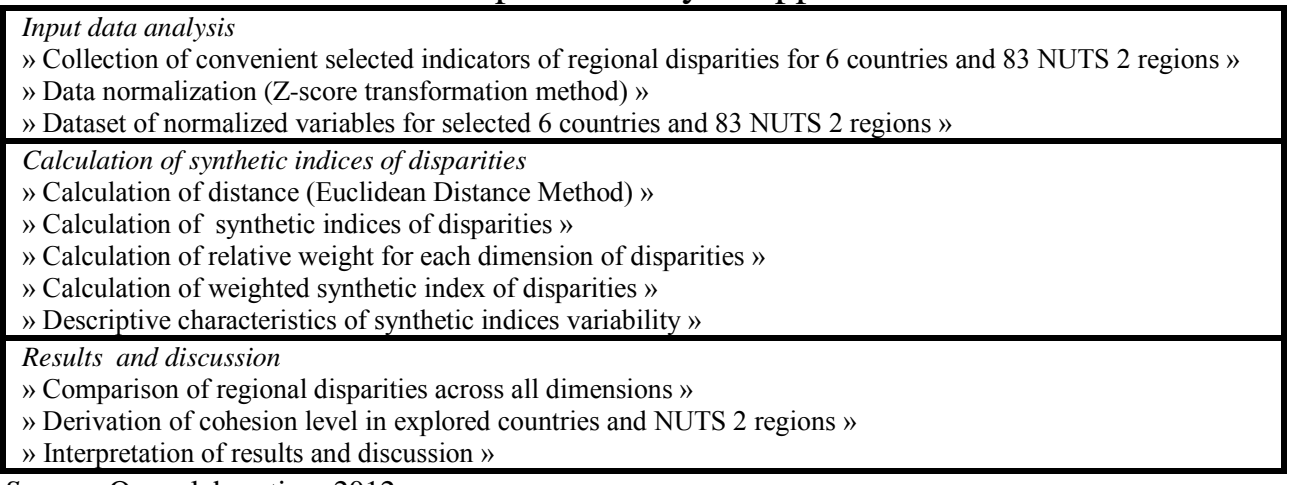

Source: Own elaboration, 2012

\subsection{Database of Disparities Indicators}

The selection of disparities indicators results from the concept of regional disparities evaluation used in the EU. The adequate indicators of regional disparities can be identified within the Reports on Economic, Social and Territorial Cohesion that evaluate the trends of disparities and cohesion in the EU Member States and their regions (European Commission, 
2007, 2010). However, the determination of appropriate and comparable regional statistics has faced the significant problems of the different (limited) availability at the regional level (NUTS 2) in comparison with national level (NUTS 0) and different length of time series (2000-2010) as mentioned also e.g. Poledníková and Lelková (2012). For the reasons mentioned above, 24 indicators on national level that represent the most frequently indicators of economic, social and territorial disparities used in Reports on Economic, Social and Territorial Cohesion have been selected (European Commission 2007, 2010), some of them represent also the EU Structural indicators. All of these indicators are available in Eurostat database and presented in Table 2.

The set of 24 indicators of disparities was not available completely for regional level. Therefore only 16 indicators of regional disparities, available in Eurostat database for the reference period 2000-2010 with same scope of availability, have been chosen for the evaluation analysis for 83 NUTS 2 regions. The economic disparities are covered by 6 selected indicators, social disparities are reflected by 6 selected indicators and territorial disparities are covered by 4 selected indicators. The selected indicators and their initial units are shown also in Table 2. The initial data matrix created by the values of 24 indicators for 6 countries and 16 indicators for 83 NUTS 2 regions of V4, Germany and Austria has been transformed to Z-score value by statistical software IBM SPSS Statistics 20 and all other following computations have been realized by Microsoft Excel 2010. The eventually missing values in the period 2000-2010 have been estimated by the method of median of nearby points in statistical software IBM SPSS Statistics 20.

\section{Table 2: Selected indicators of national (regional) disparities}

\begin{tabular}{|c|c|c|}
\hline $\begin{array}{c}\text { Type of } \\
\text { disparities }\end{array}$ & Indicator & Units \\
\hline \multirow{8}{*}{$\begin{array}{l}\text { Economic } \\
\text { disparities }\end{array}$} & GDP per head & PPS \\
\hline & Disposable income of households & PPS/head \\
\hline & Labour productivity* & $\begin{array}{l}\text { (\% GDP per person employed in PPS, EU27 } \\
=100)\end{array}$ \\
\hline & Gross fixed capital formation & Millions of euro \\
\hline & Gross domestic expenditure on research and development (GERD)* & $(\%$ of GDP) \\
\hline & Patent applications to the European Patent Office (EPO) & Number per million of inhabitants \\
\hline & Human Resources in Science and Technology & $\%$ of active population \\
\hline & Employment in technology and knowledge intensive sectors & $\%$ of active population \\
\hline \multirow{8}{*}{ Social disparities } & Employment rate & $\%$ of population aged $15-64$ \\
\hline & Employment rate of older workers & $\%$ of population aged $55-64$ \\
\hline & Employment rate of woman & $\%$ of woman population aged $15-64$ \\
\hline & Unemployment rate & $\%$ of labour force aged $15-64$ \\
\hline & Unemployment rate of youth & $\%$ of labour force aged $15-24$ \\
\hline & Long-term unemployment rate & $\%$ of labour force aged $15-64$ \\
\hline & $\begin{array}{l}\text { Employment rates by the highest level of education attained- first } \\
\text { and second stage of tertiary education* }\end{array}$ & $\%$ \\
\hline & Total public expenditure on education* & $(\%$ of GDP) \\
\hline \multirow{12}{*}{$\begin{array}{l}\text { Territorial } \\
\text { disparities }\end{array}$} & Greenhouse Gas Emissions* & (Thousands of tonnes, $\mathrm{CO} 2$ equivalent) \\
\hline & Energy intensity of the economy* & (Kilogram of oil equivalent per 1000 euro) \\
\hline & Electricity generated from renewable sources* & $(\%)$ \\
\hline & Municipal waste generation and treatment* & (Kilogram per capita) \\
\hline & Density of motorway* & $\left(\mathrm{Km} / 1000 \mathrm{~km}^{2}\right)$ \\
\hline & People killed in road accidents* & (Number of deaths per million inhabitants) \\
\hline & Infant mortality rates* & $(\%)$ \\
\hline & Volume of freight transport relative to GDP* & $($ Index $(2000=100))$ \\
\hline & Collective tourist accommodation establishments** & Number \\
\hline & Tourism intensity** & Number \\
\hline & Crude death rate $* *$ & Number per 100,000 inhabitants \\
\hline & Victims in road accident $* *$ & Number \\
\hline
\end{tabular}




\subsection{Results and Discussion}

The following figures (Figure 1 and Figure 2) show calculated average values (of individual values for the period 2000-2010) of synthetic sub-indices of economic, social and territorial disparities at national (NUTS 0) and regional (NUTS 2) level as well as calculated values of weighted (aggregate) synthetic indices. Average values of computed indices for 6 countries define the area of four polygons in Figure 1. Average values of computed indices for 83 NUTS 2 regions define the area of four polygons in Figure 2. Smaller area of polygon marks the lower rate of disparities in selected dimension and therefore the higher level of cohesion in selected dimension, country or region. The optimal form of illustrated polygons will be such a one point that would corresponds with zero value of disparities in each dimension of disparities. Smaller area of polygon marks the lower rate of disparities in selected dimension and therefore the higher level of cohesion in selected dimension, country or region. Bigger area of polygon marks the higher rate of disparities in selected dimension and therefore the smaller level of cohesion in selected dimension, country or region. The overall results presented in figures, based on the results of computed average values of synthetic indices of economic, social and territorial disparities for V4 countries, Austria and Germany and their NUTS 2 regions, sign out that the rate of disparities at national as well as at regional level in Austria and Germany is rather smaller than in all V4 countries.

The individual average values of all synthetic indices of disparities in 83 NUTS 2 regions of V4 countries, Austria and Germany are for better readability and clarity also shown in Annex 1. Average values of each synthetic index of disparities in Annex 1 are scaled by colours. Like a specific scaling method the traffic light scaling has been used. In black and white design printout of the paper, colours of traffic light scaling correspond to shades of gray. The smaller value of each synthetic index of disparities, the better ranking achieved in the various regions in overall comparison and the smaller level of disparities in various NUTS 2 regions. The smaller values of synthetic indices are shown in lighter shades of gray in Annex 1 .

Figure 1 shows the results of computed average values of synthetic indices of economic, social and territorial disparities for V4 countries, Austria and Germany in the reference period 2000-2010. Average values of synthetic indices for whole period, as well as individual values for each year of the period, sign out that the rate of disparities at national level in Austria and Germany is rather smaller than in all V4 countries according to the computed values of synthetic indices in all three dimensions of disparities. It can be said that the smaller value of calculated difference (distance) in Austria and Germany marks the lower rate of disparities in these countries and therefore the higher level of cohesion, vice versa in V4 countries. Economic disparities in V4 countries are, according to values of synthetic index, more than twice higher than in Austria (0.204) and Germany (1.620). The best results have been reached in Austria (0.204), the worst and very similar results are shown in Hungary (4.935), Poland (4.932) and Slovakia (4.926). The increasing trend of economic disparities has been recognized in Hungary and Germany after year 2008. Vice versa, the Czech Republic, Slovakia, Poland and Austria have illustrated decreasing rate of economic disparities almost in all referred period. Social disparities illustrated in Figure 1 have different trend in comparison with economic and territorial disparities. In V4 countries social disparities are, according to values of this synthetic index, also higher than in Germany (0.780) and Austria (0.350) where social disparities are the lowest. The worst results have been reached in Slovakia (4.446), Poland (3.959) and Hungary (2.691). Strong decreasing trend of social disparities has been recognized in Poland after 2004 (year of accession the EU) and directly opposite trend has been marked in Hungary after 2004. Territorial disparities in the selected countries have very similar trend in reference period in comparison with economic disparities. 
Austria (0.692) and Germany (1.512) have again reached the best results. Territorial disparities in Poland (3.974) and Slovakia (3.783) are the highest ones. High rate of territorial disparities in comparison with Austria or Germany has been also indentified in the Czech Republic (3.318) and Hungary (3.023).

Figure 1 also shows the results of the computed average values of weighted synthetic index of disparities over the period 2000-2010 for V4 countries, Austria and Germany. In terms of the smallest (smaller) value of weighted synthetic index of disparities and therefore the higher level of cohesion, the overall evaluation shows that the best results have been reached by Germany (0.773) and Austria (0.918) in comparison with V4 countries, where the best results has been proved in the Czech republic (2.654) followed by Hungary (3.617). Absolutely the highest volume of weighted synthetic index and therefore highest average rate of disparities is shown in Slovakia (4.437) a Poland (4.324).

Figure 1: Values* of synthetic indices of disparities at national (NUTS 0) level

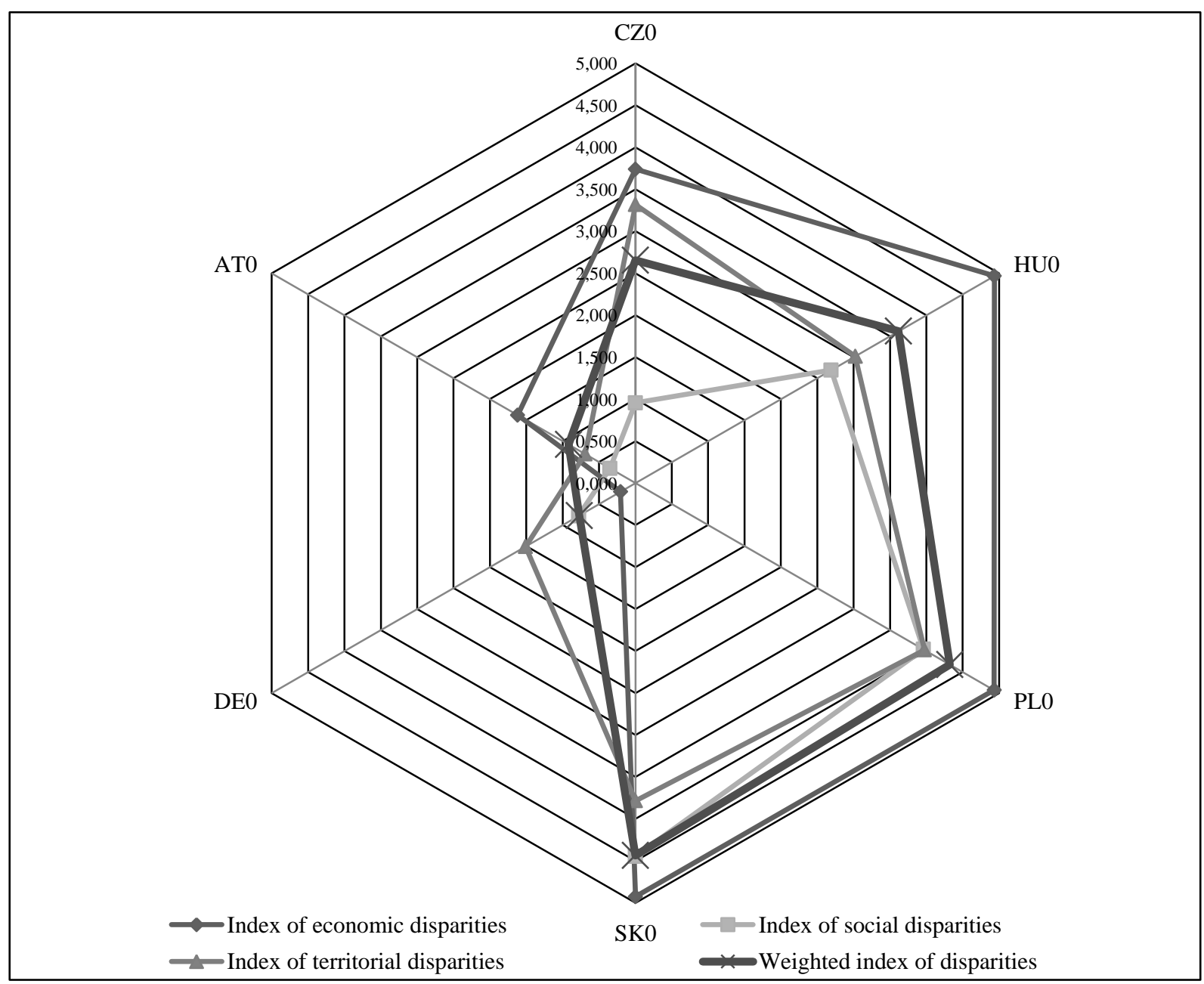

Note: * Average values calculated for each country in period 2000-2010

Source: Own calculation and elaboration, 2012

Average values of computed indices at regional level for 83 NUTS 2 regions define the area of four polygons in Figure 2. Average values of synthetic indices for the whole period, as well as individual values for each year of the period 2000-2010, sign out that the rate of disparities at regional level in most of 48 NUTS 2 regions in Austria and Germany is smaller 
than in most of 35 NUTS 2 regions of V4 countries.

Synthetic index of economic disparities for all the selected NUTS 2 regions, illustrated in Figure 2, have reached the best results (i. e. smallest level of disparities) in traditionally economic powerful regions in Germany such as for example region DE21 (Oberbayern, 0.33), DE71 (Darmstadt, 1.93) and DE11 (Stuttgart, 1.94) followed by Austria such as for example region AT13 (Wien, 4.50). According to the values of this synthetic index economic disparities in V4 regions are higher than in Germany and in some cases higher than in Austria. The smallest value of synthetic index of economic disparities in V4 countries represent region CZ01 (Prague, 7.05), HU10 (Közép-Magyarország, 8.91) and SK01 (Bratislavský kraj, 8.82).

Figure 2: Values* of synthetic indices of disparities at regional (NUTS 2) level

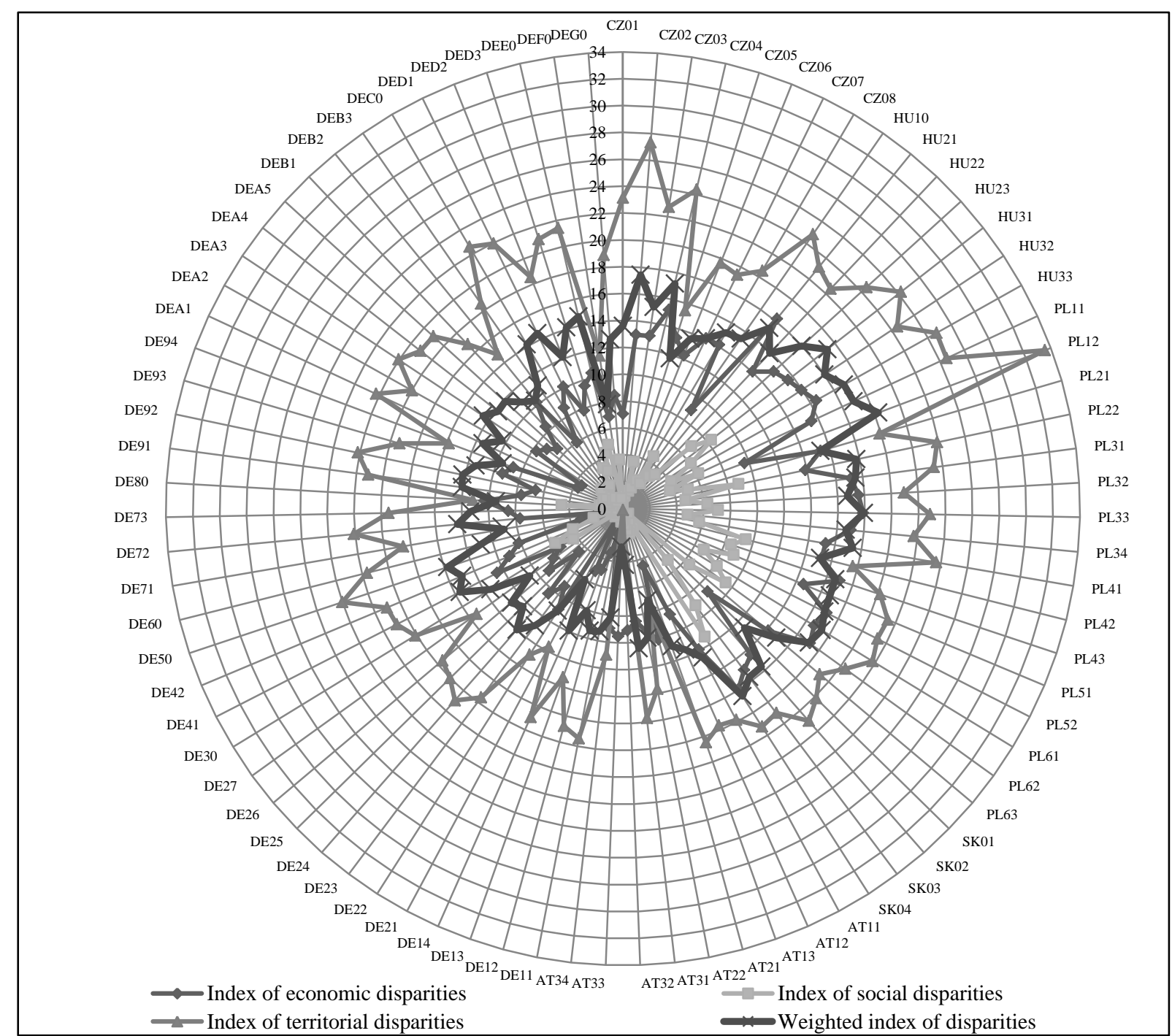

Note: * Average values calculated for each NUTS 2 region in period 2000-2010

Source: Own calculation and elaboration, 2012

Based on the results of synthetic index of social disparities, social disparities are also higher in V4 NUTS 2 regions than in Germany and most of Austrian regions although the level of social disparities is the lowest in comparison with the level of economic and territorial disparities at regional level. The smallest value of synthetic index of social disparities is represented by regions DE21 (Oberbayern, 0.14), DE13 (Freiburg, 0.15) and DE14 (Tübingen, 0.16) in Germany. There are regions AT32 (Salzburg, 0.82), AT33 (Tirol, 0.83) 
and aT34 (Vorarlberg, 0.98) with the smallest value of social disparities in Austria. The best results in social disparities have been reached by regions CZ01 (Prague, 0.26), SK01 (Bratislavský kraj, 0.56) and CZ02 (Střední Čechy, 0.89) throughout V4 countries. As Figure 2 demonstrates, the absolutely highest rate of disparities is recognized overall in territorial dimension. Based on synthetic index of territorial disparities, mainly Austrian and most of regions in Germany have reached the best (better) results than regions in V4 countries. The smallest value of synthetic index of territorial disparities has been recognized in following regions: AT 33 (Tirol, 0.10), AT32 (Salzburg, 3.03), AT21 (Kärnten, 7.67), DE80 (Mecklenburg-Vorpommern, 11.19), DEF0 (Schleswig-Holstein, 11.51) and DE21 (Oberbayern, 11.67). The highest value of synthetic index of territorial disparities has been reached in region PL12 (Mazowieckie, 33.52), CZ02 (Střední Čechy, 27.33) and HU33 (DélAlföld, 26.73). Figure 2 also shows the results of computed average values of weighted synthetic index of disparities over the period 2000-2010 for 83 NUTS 2 regions of V4 countries, Austria and Germany. The overall evaluation of individual regions shows that the best results, in terms of the smallest (smaller) value of weighted synthetic index of disparities and therefore the highest (higher) level of cohesion, have been reached in Austrian and German regions in comparison with V4 countries. NUTS 2 regions ranked in the best positions during the whole reference period are regions AT33 (Tirol, 2.85), AT32 (Salzburg, 4.20), DE21 (Oberbayern, 5.97), AT21 (Kärnten, 7.05) and DEF0 (Schleswig-Holstein, 7.84). Best results and the smallest relative value of weighted synthetic index within V4 countries have reached region CZ05 (Severovýchod, 11.71), SK01 (Bratislavský kraj, 12.65), PL63 (Pomorskie, 14.92) and HU10 (Közép-Magyarország, 15.39). Average calculated values of synthetic indices can be analyzed also through characteristics of absolute variability. We can see that the biggest range (i. e. the biggest area of polygon) is presented in territorial disparities where the average values differ from minimum 0.10 in region AT33 (Tirol) to maximum 33.52 in region PL12 (Mazowieckie). The smallest range (i. e. the smallest area of polygon) is presented in social disparities where average values differ from minimum 0.14 in region DE21 (Oberbayern) to maximum 11.31 in region SK04 (Východné Slovensko). In the middle of these ranges there are values of synthetic indices in economic disparities which differ from minimum 0.33 in region DE21 (Oberbayern) to maximum 18.18 in region HU21 (Közép-Dunántúl). The range of weighted synthetic index of regional disparities differ from the minimum value (2.85) in region AT33 (Tirol) to maximum value (20.29) in region PL12 (Mazowieckie).

\section{Conclusion}

Previous results presented at national and regional level indicates disparities between V4 countries and their regions on the one hand and Germany and Austria as more developed states on the other hand. Based on the analysis of the results mentioned above, the initial presumption of the paper that the national (and also regional) level of disparities in Austria and Germany is lower than level of disparities in V4 countries and their regions has been confirmed. The analysis also showed that in most cases there was a consensus in the development trends of V4 countries in terms of attainment level of development potential to advanced countries as Austria and Germany, depending on the level of existing disparities. Synthetic indices of disparities also showed that during most part of the reference period (2000-2008), a positive development in economic, social and territorial disparities has been monitored in all the countries and most of NUTS 2 regions and thus level of cohesion recorded increasing trend thanks to the decreasing volume of national or regional disparities. The performed analysis also showed that economic disparities at national level and territorial disparities at regional level between V4 countries, Germany and Austria achieved the highest rate of absolute variability. 


\section{Acknowledgement}

This paper was created under SGS project (SP2012/153) of Faculty of Economics, VŠBTechnical University of Ostrava.

\section{References}

[1] AMENDOLA, A., F. E. CAROLEO and G. COPPOLA, 2004. Regional Disparities in Europe. Discussion Paper. 78. Università degli Studi di Salerno. Centro di Economia del Lavoro e di Politica Economica.

[2] BÁRCENA, A., A. PRADO, L. BECCARIA and S. MALCHIK, 2010. Social Cohesion in Latin America - Concepts, frames of reference and indicators [online]. United Nations [cit. 15 ${ }^{\text {th }}$ December 2012]. Accessible from: http://www.eclac.org/publicaciones/xml/1/42251/LCG2420i.pdf

[3] BELL, N., N. SCHUURMAN and M. V. HAYES, 2007. Using GIS-based methods of multicriteria analysis to construct socio-economic deprivation indices. International Journal of Health Geographic [online]. 6 (17) [cit. 29 ${ }^{\text {th }}$ June 2013]. ISSN 1476-072X. Accessible from: http://www.ij-healthgeographics.com/content/6/1/17

[4] DVOROKOVÁ, K., J. KOVÁŘOVÁ a M. ŠULGÁNOVÁ, 2011. Ekonometrické modelování konvergence ekonomické a cenové úrovně. Analýza průřezových a panelových dat. Series on Advanced Economic Issues, Vol. 11. Ostrava: VŠB-TU. ISBN 978-80-248-2543-4.

[5] ECONOMIC AND SOCIAL RESEARCH INSTITUTE, 2008. Using GIS to Promote Regional and Local Economic Development for Utilities. ESRI White Paper [online]. pp. 1-17 [cit. 29 $9^{\text {th }}$ June 2013]. ISSN Accessible from: http://www.esri.com/library/whitepapers/pdfs/gis-ecodev-utilities.pdf

[6] EUROPEAN COMMISSION, 2007. Growing Regions, Growing Europe. Forth Report on Economic and Social Cohesion. Luxembourg: Office for Official Publications of the European Communities. ISBN 92-79-05704-5222.

[7] EUROPEAN COMMISSION, 2010. Fifth report on economic, social and territorial cohesion - Investing in Europe's future. Brussels: European Commission. ISBN 978-9279-17800-9.

[8] EUROSTAT, 2012. Regions and cities. Regional Statistics [online]. [cit. $16^{\text {th }}$ November 2012]. Accessible from: http://epp.eurostat.ec.europa.eu/portal/page/portal/ region_cities/regional_statistics/data/database

[9] FARRUGIA, N. and A. GALLINA, 2008. Developing Indicators of Territorial Cohesion. Federico Caffe Centre - Department of Society and Globalization. ISSN 1396-5085.

[10] GULATI, R. K., 1999. Regional disparities and economic development. Policies and prospects for balanced regional development. New Delhi: Deep \& Deep Publications. ISBN 81-7629-194-3.

[11] HANČLOVÁ, J. et al., 2010. Makroekonomické modelování české ekonomiky a vybraných ekonomik EU. Ostrava: VŠB-TU Ostrava. ISBN 978-80-248-2353-9.

[12] HUANG, Y. and Y. LEUNG, 2009. Measuring Regional Inequality: A Comparison of Coefficient of Variation and Hoover Concentration Index. The Open Geography Journal [online]. 2, 25-34 [cit. 29 ${ }^{\text {th }}$ June 2013]. ISSN 1874-9232. Accessible from: http://www.benthamscience.com/open/togeogj/articles/V002/25TOGEOGJ.pdf 
[13] KŘUPKA, J., R. PROVAZNÍKOVÁ a J. ŠVEJCAR, 2011. Multiple Criteria Decision Analysis of EU Project Implementation Benefits for the Impacted Micro-region. International Journal of Mathematical Models and Methods in Applied Science, 8(5), 1354-1362. ISSN 1998-0140.

[14] KUTSCHERAUER, A. et al., 2010. Regionální disparity. Disparity v regionálním rozvoji země, jejich pojetí, identifikace a hodnocení. Series on Advanced Economic Issues, Vol. 3. Ostrava: VŠB-TU Ostrava. ISBN 978- 80-248-2335-5.

[15] LEONARDI, R., 2005. Cohesion Policy in the European Union: The Building Europe. New York: Palgrave Macmillan. ISBN 1403949557

[16] MELECKÝ, L., 2012. Evaluation of Cohesion in Visegrad Countries in Comparison with Germany and Austria by Multivariate Methods for Disparities Measurement. International Journal of Mathematical Models and Methods in Applied Sciences, 8(6), 979-989. ISSN 1998-0140.

[17] MOLLE, W., 2007. European Cohesion Policy: Regions and Cities. London: Routledge. ISBN -415-43811-X.

[18] PETR, P., J. KŘUPKA a R. PROVAZNÍKOVÁ, 2011. Multidimensional Modelling of Cohesion Regions. International Journal of Mathematical Models and Methods in Applied Science, 1(5), 150-158. ISSN 1998-0140.

[19] POLEDNÍKOVÁ, E. a P. LELKOVÁ, 2012. Evaluation of Regional Disparities in Visegrad Four Countries, Germany and Austria using the Cluster Analysis. In: $X V$. Mezinárodní kolokvium o regionálních védách. Brno: Masarykova univerzita, pp. 3647. ISBN 978-80-210-5875-0.

[20] STANÍČKOVÁ, M. a K. SKOKAN, 2012. Evaluation of the EU Member States Efficiency by Data Envelopment Analysis Method. International Journal of Mathematical Models and Methods in Applied Sciences, 2(6), 349-357. ISSN 19980140 .

[21] TULEJA, P., 2008. Metody měření regionálních disparit v územním rozvoji České republiky. Regionální disparity, 2, 15 - 33. ISSN 1802-9450.

[22] TULEJA, P., 2010. Praktická aplikace vybraných metod měření regionálních disparit na oblast sociální vybavenosti regionů. Regionální disparity, 7, $5-23$. ISSN 18029450.

[23] TVRDON, M. a K. SKOKAN, 2011. Regional disparities and the ways of their measurement: The case of the Visegrad Four countries, Technological and Economic Development of Economy, 17(3), 501-518. ISSN 1392-8619.

[24] VITURKA, M., 2010. Regionální disparity a jejich hodnocení v kontextu regionální politiky. GEOGRAFIE. 2, 131-143. ISSN 1212-0014.

[25] VOJINOVIC, B. and Ž. J. OPLOTNIK, 2008. Real Convergence in the New EU Member States. Prague Economic Papers, 1, 23-39. ISSN 1210-0455.

[26] VOJVODÍKOVÁ, B. et al., 2010. Návrh hodnotícího modelu pro posouzení disparit a metodický postup pro jeho využivání. Závěrečná zpráva projektu WD-41-07-1 [online]. Ostrava, [cit. 14 ${ }^{\text {th }}$ May 2012]. Accessible from: http://hmdis.ataco.cz/export/sites/hmdis/cs/vysledky/zpravy/dilci_zprava_dc1.pdf

[27] WISHLADE, F. and D. YUILL, 1997. Measuring Disparities for Area Designation Purposes: Issues for the European Union. Regional and Industrial Policy Research 
Paper [online]. 24, 2-32 [cit. 29 ${ }^{\text {th }}$ June 2013]. Accessible from: http://www.eprc.strath.ac.uk/eprc/documents/pdf_files/r24measdispforareadesigpurpose s.pdf

[28] WOODBURY, G., 2001 An Introduction to Statistics. Cengage Learning. ISBN 0534377556. 
Annex 1: Average values of synthetic indices calculated for each NUTS 2 region in period 2000-2010*

\begin{tabular}{|c|c|c|c|c|}
\hline NUTS 2 & IED** & ISD $* * *$ & ITD**** & WID $* * * * *$ \\
\hline CZ01 & 7,05 & 0,26 & 23,13 & 13,59 \\
\hline $\mathrm{CZ} 02$ & 12,98 & 0,89 & 27,33 & 17,46 \\
\hline $\mathrm{CZ} 03$ & 13,00 & 0,96 & 22,70 & 15,17 \\
\hline CZ04 & 15,19 & 3,58 & 24,36 & 17,19 \\
\hline CZ05 & 13,32 & 1,36 & 15,46 & 11,71 \\
\hline CZ06 & 12,28 & 1,67 & 19,68 & 13,61 \\
\hline $\mathrm{CZ} 07$ & 14,10 & 2,34 & 19,38 & 14,11 \\
\hline CZ08 & 14,14 & 4,51 & 20,52 & 15,18 \\
\hline HU10 & 8,91 & 2,27 & 24,82 & 15,39 \\
\hline HU21 & 18,18 & 3,10 & 23,17 & 17,30 \\
\hline HU22 & 14,04 & 3,46 & 22,49 & 15,90 \\
\hline HU23 & 15,15 & 6,89 & 24,48 & 17,97 \\
\hline HU31 & 15,57 & 8,32 & 26,23 & 19,29 \\
\hline HU32 & 15,92 & 6,08 & 24,49 & 18,01 \\
\hline HU33 & 16,48 & 4,12 & 26,73 & 18,85 \\
\hline PL11 & 15,46 & 6,19 & 26,55 & 18,94 \\
\hline PL12 & 9,65 & 3,75 & 33,52 & 20,29 \\
\hline PL21 & 15,32 & 5,04 & 19,88 & 15,30 \\
\hline PL22 & 13,88 & 8,79 & 23,88 & 17,75 \\
\hline PL31 & 17,11 & 4,71 & 23,33 & 17,45 \\
\hline PL32 & 17,55 & 6,30 & 20,94 & 16,73 \\
\hline PL33 & 17,87 & 7,10 & 22,85 & 17,95 \\
\hline PL34 & 17,02 & 4,85 & 21,72 & 16,65 \\
\hline PL41 & 15,31 & 5,77 & 23,64 & 17,35 \\
\hline PL42 & 15,22 & 9,43 & 17,62 & 15,13 \\
\hline PL43 & 16,98 & 8,48 & 20,16 & 16,67 \\
\hline PL51 & 14,56 & 8,94 & 21,36 & 16,71 \\
\hline PL52 & 17,02 & 6,76 & 21,26 & 16,85 \\
\hline PL61 & 16,68 & 8,21 & 21,76 & 17,33 \\
\hline PL62 & 17,14 & 9,43 & 20,40 & 17,05 \\
\hline PL63 & 14,12 & 6,48 & 19,13 & 14,92 \\
\hline SK01 & 8,82 & 0,56 & 20,15 & 12,65 \\
\hline SK02 & 14,45 & 5,09 & 21,00 & 15,64 \\
\hline SK03 & 15,01 & 9,02 & 19,02 & 15,67 \\
\hline SK04 & 15,98 & 11,31 & 19,23 & 16,56 \\
\hline AT11 & 11,92 & 1,63 & 17,84 & 12,58 \\
\hline AT12 & 8,60 & 1,20 & 17,64 & 11,47 \\
\hline AT13 & 4,50 & 1,76 & 18,47 & 10,88 \\
\hline AT21 & 10,10 & 1,91 & 7,67 & 7,05 \\
\hline AT22 & 9,31 & 1,65 & 13,67 & 9,78 \\
\hline AT31 & 8,44 & 1,23 & 15,71 & 10,46 \\
\hline AT32 & 9,08 & 0,82 & 3,03 & 4,20 \\
\hline AT33 & 9,53 & 0,83 & 0,10 & 2,85 \\
\hline AT34 & 8,97 & 0,98 & 10,95 & 8,17 \\
\hline DE11 & 1,94 & 0,19 & 17,42 & 9,30 \\
\hline DE12 & 3,41 & 0,40 & 16,78 & 9,43 \\
\hline DE13 & 4,84 & 0,15 & 13,33 & 8,04 \\
\hline DE14 & 5,08 & 0,16 & 16,98 & 9,94 \\
\hline DE21 & 0,33 & 0,14 & 11,67 & 5,97 \\
\hline DE22 & 8,91 & 0,37 & 12,91 & 9,00 \\
\hline DE23 & 7,23 & 0,45 & 17,57 & 10,89 \\
\hline DE24 & 8,42 & 0,81 & 18,97 & 12,00 \\
\hline DE25 & 4,56 & 0,54 & 18,03 & 10,41 \\
\hline DE26 & 7,19 & 0,45 & 17,56 & 10,88 \\
\hline NUTS 2 & IED** & ISD $* * *$ & ITD***** & WID $* * * * *$ \\
\hline DE27 & 6,35 & 0,27 & 13,41 & 8,53 \\
\hline DE30 & 5,44 & 4,32 & 18,11 & 11,54 \\
\hline DE41 & 10,52 & 5,64 & 18,90 & 13,63 \\
\hline
\end{tabular}

\begin{tabular}{|c|c|c|c|c|}
\cline { 2 - 5 } DE42 & 9,15 & 4,02 & 19,04 & $\mathbf{1 2 , 9 6}$ \\
\hline DE50 & 8,15 & 2,30 & 22,00 & $\mathbf{1 3 , 7 8}$ \\
\hline DE60 & 3,20 & 0,86 & 19,63 & $\mathbf{1 0 , 9 0}$ \\
\hline DE71 & 1,93 & 0,58 & 16,59 & $\mathbf{8 , 9 7}$ \\
\hline DE72 & 7,69 & 0,80 & 20,11 & $\mathbf{1 2 , 3 7}$ \\
\hline DE73 & 8,54 & 1,17 & 17,44 & $\mathbf{1 1 , 3 5}$ \\
\hline DE80 & 10,33 & 4,56 & 11,19 & $\mathbf{9 , 4 7}$ \\
\hline DE91 & 7,64 & 1,73 & 19,13 & $\mathbf{1 2 , 0 7}$ \\
\hline DE92 & 6,64 & 1,25 & 20,17 & $\mathbf{1 2 , 2 1}$ \\
\hline DE93 & 9,34 & 0,80 & 17,33 & $\mathbf{1 1 , 4 3}$ \\
\hline DE94 & 8,72 & 1,06 & 13,83 & $\mathbf{9 , 5 6}$ \\
\hline DEA1 & 3,69 & 1,59 & 20,25 & $\mathbf{1 1 , 5 2}$ \\
\hline DEA2 & 3,50 & 1,37 & 17,99 & $\mathbf{1 0 , 2 8}$ \\
\hline DEA3 & 7,73 & 1,47 & 20,05 & $\mathbf{1 2 , 5 0}$ \\
\hline DEA4 & 7,18 & 0,96 & 19,11 & $\mathbf{1 1 , 7 6}$ \\
\hline DEA5 & 6,62 & 2,14 & 19,08 & $\mathbf{1 1 , 8 6}$ \\
\hline DEB1 & 8,39 & 0,79 & 16,83 & $\mathbf{1 0 , 9 1}$ \\
\hline DEB2 & 10,20 & 0,65 & 14,76 & $\mathbf{1 0 , 3 5}$ \\
\hline DEB3 & 5,98 & 0,94 & 18,54 & $\mathbf{1 1 , 1 5}$ \\
\hline DEC0 & 8,70 & 1,97 & 22,59 & $\mathbf{1 4 , 1 5}$ \\
\hline DED1 & 10,10 & 3,34 & 21,95 & $\mathbf{1 4 , 5 2}$ \\
\hline DED2 & 7,87 & 3,00 & 18,54 & $\mathbf{1 2 , 1 3}$ \\
\hline DED3 & 9,57 & 4,34 & 21,01 & $\mathbf{1 4 , 1 3}$ \\
\hline DEE0 & 10,35 & 4,86 & 21,44 & $\mathbf{1 4 , 6 7}$ \\
\hline DEF0 & 6,91 & 0,76 & 11,51 & $\mathbf{7 , 8 4}$ \\
\hline DEG0 & 8,45 & 3,64 & 18,94 & $\mathbf{1 2 , 6 3}$ \\
\hline
\end{tabular}

Note: * In black and white design printout of the paper, colours of traffic light scaling correspond to shades of gray. The smaller value of individual synthetic index presents the smaller level of disparities in various NUTS 2 regions and they are shown in lighter shades of gray

$* *$ IED $=$ Index of Economic Disparities

$* * *$ ISD $=$ Index of Social Disparities

$* * * *$ ITD $=$ Index of Territorial Disparities

$* * * * *$ WID $=$ Weighted Index of Disparities

Source: Own calculation and elaboration, 2012 